\title{
Antimicrobial profile of crude extracts Calotropis procera and Centella asiatica against some important pathogens
}

\author{
Varahalarao Vadlapudi ${ }^{1^{*}}$, Mohan Behara ${ }^{2}$, D.S.V.G.K.Kaladhar ${ }^{3}$, S.V.N .Suresh kumar ${ }^{4}$, B. Seshagiri ${ }^{5}$ and M. John \\ paul $^{6}$ \\ ${ }^{1 *}$ Department of Biochemistry, Dr Lankapalli Bullayya PG College, Visakhapatnam-530013, AP, India. \\ ${ }^{2}$ Department of Botany, P.V.K.N. Govt. College, Chitoor - 517 002, AP, India \\ ${ }^{3}$ Department of Bioinformatics, GIS, GITAM University, Visakhapatnam-530045, AP, India \\ ${ }^{4}$ Department of Biochemistry, Degree and P G College, Kakinada-533001, AP, India \\ ${ }^{5}$ Department of Environmental Sciences, Andhra University, Visakhapatnam - 530 003, AP, India \\ ${ }^{6}$ Department of Botany, P.R.R and V.S Government Degree College, Nellore- -524 318, Vidavalur, AP, India \\ drvadlapudi@yahoo.in*
}

\begin{abstract}
To investigate in vitro antimicrobial activity of aerial parts of Calotropis procera and Centella asatica Linn., that have been popularly used as folk medicines. The organic solvent plant extracts are tested on the various microorganisms including bacteria and fungi using agar well diffusion technique. The length of the inhibition zone was measured in millimeters from the edge of the well to the edge of the inhibition zone. C. procera showed significant to moderate activity against $(14 \mathrm{~mm})$ Pseudomonas marginalis and $(21 \mathrm{~mm})$ Streptococcus mutans with $100 \mathrm{mg} / \mathrm{ml}$ DMSO plant drug concentration. The results of (MICs) values are lowest at 66 and highest at $152 \mathrm{mg} / \mathrm{ml}$ for $C$. procera whereas 0 to $155 \mathrm{mg} / \mathrm{ml}$ for $C$. asatica. The extracts were assessed in an effort to validate the potential activity of the medicinal plants against microbes.
\end{abstract}

Keywords: Calotropis procera, Centella asiatica, Soxhlet extraction, Inhibition zone.

Introduction

According to a study conducted by the World Health Organization (WHO) based on publications on pharmacopoeias and medicinal plants in 91 countries, the number of medicinal plants is nearly 21000 . Nearly 6-7 thousand species of medicinal plants out of about 17-18 thousand flowering plants are known to be in use in folk and officially recognized systems of medicine in India, i.e., Ayurveda, Sidha, Unani and Homeopathy.

India has a rich heritage of knowledge on plant based drugs both for use in preventive and curative medicine. From ancient civilization the various parts of different plants were used to eliminate pain, control suffering and counteract disease. Plants generally produce many secondary metabolites which constitute an important source of microbicides, pesticides and many pharmaceutical drugs. It has also been widely observed and accepted that the medicinal value of plants lies in the bioactive phytocomponents present in the plants (Veeramuthu et al., 2006; Khan \& Khan 2008; Ghosh et al., 2008; Mandal et al., 2010; Abubakar et al., 2011). Much work has been done on ethnomedicinal plants in India (Nair 2005; Rout et al., 2009; Madhuri Sharma \& Pandey Govind, 2009). Medicinal plants represent a rich source of antimicrobial agents (Kannan, et al., 2007; Jeeshna et al., 2009; Jarrar et al., 2010; Johnson et al., 2010; Koochak et al., 2010). Because of the side effects and the resistance that pathogenic microorganisms build against antibiotics, many scientists have recently paid attention to extracts and biologically active compounds isolated from plant species used in herbal medicines (Mst Nazma Yesmin et al., 2008).

Calotropis procera Linn. (Family Asclepiadaceae) is a shrub or small tree up to $2.5 \mathrm{~m}$ height. All parts of the plant exude white latex when cut or broken. It is known by various names like swallow wort, dead sea apple, sodom apple or milk weed, commonly used and known as Arka or Madar. Telugu name is Jilledachetta and in english calotrope, calotropis, Dead Sea fruit, desert wick, giant milkweed, mudar fibre, rubber bush, rubber tree, sodom apple, swallow, wort. In the traditional Indian medicinal system, it has been used for Pain, asthma, bronchitis, and dyspepsia, leprosy, ulcers, tumors, piles, spleen, liver and abdomen. The root bark in the form of paste with rice vinegar is applied to elephantiasis of the legs and scrotum. The plant is also known for its toxic properties that include iridocyclitis, dermatitis and acts like a poison and produces lethal effects. Compounds derived from the plant have been found to have emeto, cathartic and digitalic properties. Antimicrobial activity of $C$. procera was previously screened by (Kareem et al., 2008; Varahalarao Vadlapudi et al., 2004). In the leaves, mudarine is the principal active constituent as well as a bitter yellow acid, resin and 3 toxic glycosides calotropin, uscharin and calotoxin. The latex contains a powerful bacteriolytic enzyme, a very toxic glycoside calactin (the concentration of which is increased following insect or grasshopper attack as a defense mechanism), calotropin D I, calotropin D II, calotropin F I, calotropin F II and a non toxic protealytic enzyme calotropin (2\% to $3 \%)$. This calotropin is more proteolytic than papain, and bromelain
Research article

(C)Indian Society for Education and Environment (iSee)
"Medicinal plant"

http://www.indjst.org
V.Vadlapudi Indian J.Sci.Technol. 
coagulates milk and digests meat, gelatin and casein. The whole plant contains a, and b-amyrin, teraxasterol, gigantin, giganteol, isogiganteol, b-sitosterol and a wax.

Centella asiatica (Family Mackinlayaceae) common names include Gotu Kola, Asiatic Pennywort, Indian Pennywort, Luei Gong Gen, Takip, kohol, Antanan, Pegagan, Pegaga, vallaarai Kula kud, Bai Bua Bok and Brahmi. In India famous as "Brahmi" it is used for improving the mental ability as was carried out at Dr. A. Lakshmipathy Research Centre (now under CCRAS) VHS, Adyar, Chennai (Appa Rao et al., 1973). Antibacterial activity of $C$. asiatica was previously screened by (Rohini kiran Kunta et al., 2004).

The aim of the present study was to investigate in vitro antimicrobial activity of Indian medicinal plants $C$. procera and $C$. asatica Linn against the resistant pathogens. In this paper we report the results of such studies in order to orient future investigations towards the finding of potent, less toxic to human health and safe antimicrobial agents from natural sources.

Fig. 1. Antimicrobial activity of methanol extracts C. procera

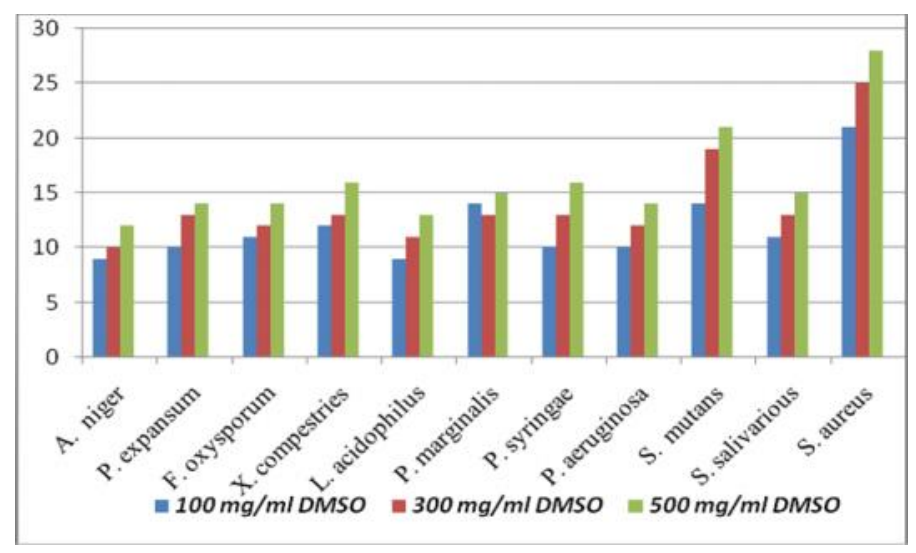

Fig. 2. Antimicrobial activity of methanol extracts C. asiatica

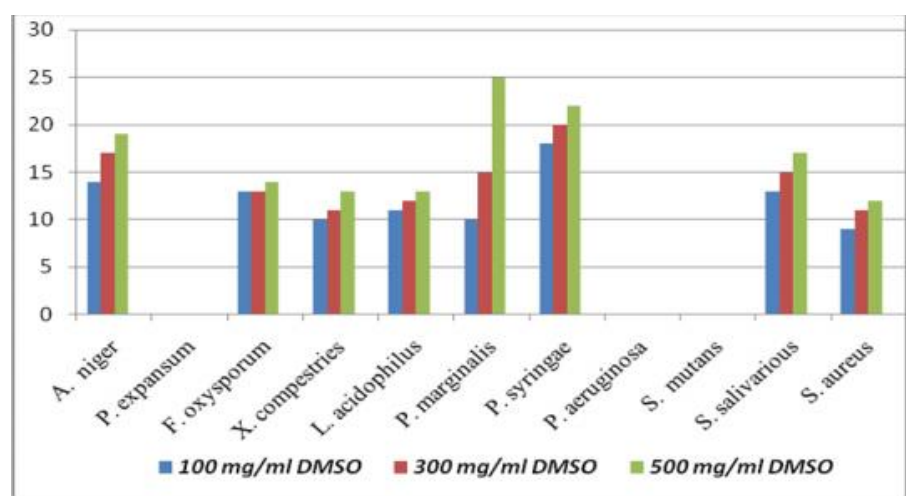

\section{Materials and methods}

Solvents and chemicals used: All chemicals were purchased from Merck, Qualigens fine Chemicals and SD fine chemicals, Mumbai.

Research article

COIndian Society for Education and Environment (iSee)

\section{Plant material and extraction}

C. procera and C. asatica plants were taxonomically identified by Prof K.C. Naidu, Department of Botany, Andhra University and the Voucher specimen is stored in the Department of Botany, Andhra University, Visakhapatnam, India. The aerial plant parts were collected for the period 2009-2010 from Visakhapatnam area, Andhra Pradesh, India. The plant material were dried under shade with occasional shifting and then powdered with a mechanical grinder and stored in an airtight container. The powder obtained was subjected to successive soxhlet extraction with organic solvents with increasing order of polarity i.e. Hexane, Chloroform and Methanol respectively for two days at above the boiling point.

\section{Test microorganisms}

Microbial strains of clinical, plant and aquatic origin i.e. Asperigellus niger (MTCC 2723), Pencillium expansum (MTCC 2006), Fusarium oxysporum (MTCC 1755), Xanthomonas compestries (MTCC 2286), Lactobacillus acidophilus (MTCC 447), Pseudomonas marginalis (MTCC), Pseudomonas syringae (MTCC 1604), Pseudomonas aeruginosa (MTCC 1688), Streptococcus mutans (MTCC 890), Steptococcus salivarious (MTCC 1938) and Staphylococcus aureus (MTCC) including both fungi and bacteria were procured from Microbial Type Culture Collection (MTCC), Chandigarh. Active cultures were generated by inoculating a loopful of culture in separate $100 \mathrm{~mL}$ nutrient/potato dextrose broths and incubating on a shaker at $370 \mathrm{C}$ overnight. The cells were harvested by centrifuging at $4000 \mathrm{rpm}$ for $5 \mathrm{~min}$, washed with normal saline, spun at $4000 \mathrm{rpm}$ for $5 \mathrm{~min}$ again and diluted in normal saline to obtain $5 \times 10^{5} \mathrm{cfu} / \mathrm{mL}$.

\section{Determination of antimicrobial activity}

The crude extracts of the different plant parts of different species were subjected to antimicrobial assay using the agar well diffusion method of Murray et al. (2004) modified by Olurinola (2004). $20 \mathrm{ml}$ of nutrient agar was dispensed into sterile universal bottles. Then inoculated with $0.2 \mathrm{ml}$ of cultures mixed gently and poured into sterile petri dishes. After setting a number 3cup borer $(6 \mathrm{~mm}$ diameter) was properly sterilized by flaming and used to make three to five uniform cups/wells in each petri dish. A drop of molten nutrient agar was used to seal the base of each cup. The cups/wells were filled with $50 \mu \mathrm{l}$ of the extract concentrations of 100,300 and $500 \mathrm{mg} / \mathrm{ml}$ DMSO and allow diffusing for 45 minutes. The solvents used for reconstituting the extracts were similarly analyzed. The plates were incubated at $37^{\circ} \mathrm{C}$ for 24 hours for bacteria. The above procedure is allowed for fungal assays but except the media potato dextrose agar instead of nutrient agar and incubates at $25^{\circ} \mathrm{C}$ for 48 hours. The zones of inhibition were measured with antibiotic zone scale in $\mathrm{mm}$ and the experiment was carried out in duplicates.
"Medicinal plant"

http://www.indjst.org
V.Vadlapudi Indian J.Sci.Technol. 
Table 1. Antimicrobial activity of methanolic extracts C. procera and C. asiatica

\begin{tabular}{|l|l|l|l|l|l|l|l|l|}
\hline \multicolumn{1}{|c}{ C. procera } & \multicolumn{3}{|c|}{ C. asatica } \\
\hline Pathogens & $\mathrm{A}$ & $\mathrm{B}$ & $\mathrm{C}$ & $\mathrm{MIC}$ & $\mathrm{A}$ & $\mathrm{B}$ & $\mathrm{C}$ & $\mathrm{MIC}$ \\
\hline A. niger & 9 & 10 & 12 & 152 & 14 & 17 & 19 & 65 \\
\hline P. expansum & 10 & 13 & 14 & 100 & 0 & 0 & 0 & 0 \\
\hline F. oxysporum & 11 & 12 & 14 & 104 & 13 & 13 & 14 & 95 \\
\hline X. compestries & 12 & 13 & 16 & 80 & 10 & 11 & 13 & 152 \\
\hline L. acidophilus & 9 & 11 & 13 & 120 & 11 & 12 & 13 & 155 \\
\hline P. marginalis & 14 & 13 & 15 & 83 & 10 & 15 & 25 & 144 \\
\hline P. syringae & 10 & 13 & 16 & 140 & 18 & 20 & 22 & 80 \\
\hline P. aeruginosa & 10 & 12 & 14 & 110 & 0 & 0 & 0 & 0 \\
\hline S. mutans & 14 & 19 & 21 & 100 & 0 & 0 & 0 & 0 \\
\hline S. salivarious & 11 & 13 & 15 & 100 & 13 & 15 & 17 & 127 \\
\hline S. aureus & 21 & 25 & 28 & 66 & 9 & 11 & 12 & 147 \\
\hline
\end{tabular}

(0) Value indicates no activity, Volume per well: $50 \mu$ l, Borer size used: $6 \mathrm{~mm}$ used Plant Methanolic extract concentrations $(A=100$, $B=300$, and $C=500 \mathrm{mg} / \mathrm{DMSO} \mathrm{ml}$ ) MIC-Minimum inhibitory concentration

\section{Minimum inhibitory concentration (MIC) assays}

Based on the literature, the medicinal properties were identified to have potent antimicrobial activity and Minimum Inhibitory Concentrations (MIC) of the extracts was determined according to (Elizabeth et al., 1999).

\section{Results and discussion}

In the present study methanolic extract exhibited different degree of growth inhibition against the tested bacterial and fungal strains. According to Fig. 1, 2 and Table 1, methanolic extracts of $C$. procera and $C$. asatica exhibited considerable antimicrobial activity against tested microbial strains. C. rocera shown significant to moderate activity against $P$. marginalis and $S$. mutans with $100 \mathrm{mg} / \mathrm{ml}$ DMSO plant drug concentration. $C$. asatica is significant against $P$. syringae and moderate against other pathogens $F$. oxysporum, $L$. acidophilus, $S$. salivarious and $S$. aureus with $100 \mathrm{mg} / \mathrm{ml}$ DMSO.

The results of MICs values are lowest at 66 and highest at $152 \mathrm{mg} / \mathrm{ml}$ for $C$. procera whereas $0,155 \mathrm{mg} / \mathrm{ml}$ for $C$. asatica. The variation of antimicrobial activity of our extracts might be due to the distribution of antimicrobial substances, which varied from fraction to fraction of the crude extract. No inhibitions were observed with $C$. procera on $P$. expansum and $C$. asatica on $P$. aeruginosa and $S$. mutans.

These extracts are harmless and nonphytotoxic; it has been proved that extracts have inhibitory effects on germination and on the viability of fungal spores as well. Both plant extracts showed moderate to good activity against $A$. niger as it is a saprophyte in soil causing black mould of onion, garlic and shallot, stem rot of Dracaena, root stalk rot of Sansevieria, and boll rot of cotton; spoilage of cashew kernels, dates, figs, vanilla pods and dried prune.

The effectiveness of the active compounds present in plant extracts causes the production of growth inhibition zones that appear as clear are as surrounding the wells. However, plant extract was unable to exhibit antibacterial activity against tested bacterial strains. These bacterial strains may have some kind of resistance mechanisms e.g. enzymatic inactivation, target sites modification and decrease intracellular drug accumulation (Schwarz \& Noble, 1999) or the concentration of the compound used may not be sufficient.

The adverse effects of $C$. procera consumption are reported to cause blisters, lesions and eruptions when taken by patients for the treatment of joint pains and gastrointestinal problems. Due to its toxicity, the latex extracted from the stem has traditionally been used to make poison arrows. The latex is highly toxic to human eyes and produces sudden painless dimness of vision with photophobia (Basak et al., 2009).

Several phytochemicals are identified in different parts. C. procera flowers contain terpenes, multiflorenol, and cyclisadol (Al-Yahya et al., 1990). The latex contains caoutchouc, calotropin, calotoxin 0.15 $\%$, calactin $0.15 \%$, uscharin $0.45 \%$, trypsin, voruscharin, uzarigenin, syriogenin and proceroside (Atef et al., 1999). Chemical constituents of $C$. procera flowers are lupeol, uscharin, proceroside, proceragenin (cardenolide), syriogenin, taraxast-20 (30)-en-3-(4-methyl-3pentenoate), 3-thiazoline cardenolide, gigantin, giganteol, isogiganteol, uscharidin, uzarigenin voruscharin a, calotropeol, 3 - epimoretenol, a-lactuceryl acetate and alactuceryl isovalerate (Ansari \& Ali 1999). Root bark of Calotropis procera contains triterpenes, A new norditerpenyl ester, named Calotropterpenyl ester, and two unknown pentacyclic triterpinoids, namely calotropursenyl acetate and calotropfriedelenyl acetate, akundarol isovalerate, mundarol isovalerate and quercetin, 3 - rutinoside (Akhtar and Malik., 1998; Ansari et al., 2001). The principal active medicinals are asclepin and mudarin (Raghubir et al., 1999).

No inhibition was observed with controls, which proves that solvents could not act as antimicrobial agents. In almost all tests, crude methanolic extracts showed better inhibition against all the tested bacterial and fungal strains, indicating that active ingredients in plant materials could be extracted into methanol.

However, the highest antibacterial activity of $C$. procera was observed due to the presence of secondary metabolites such as alkaloids, flavonoids and steroids against $S$. aureus.

$P$. aeruginosa are wide spread in soil, water and sewage and this can be considered as an indication of their involvement in the natural process of mineralization of organic matter. It has long been a troublesome cause of secondary infections of wound, especially burns, giving rise to blue green pus. It produces meningitis, when introduced by lumber puncture and urinary tract infection when introduced by catheters and instruments or irrigating solutions (Willey et al., 2008). S. aureus occur harmlessly as a normal flora of the skin and mucous membrane and it is one of the commonest bacterial 
pathogens encountered in the community causing severe food poisoning or minor skin infections to severe life threatening infections (Brooks et al., 2004).

C. asiatica methanol extract having strong inhibition activity against $P$. aeruginosa and $S$. aureus was previously reported by (Thangavel Arumugam et al., 2011).

Conclusions

Plants extracts of $C$. procera and $C$. asatica showed antimicrobial activity against tested pathogens including antibiotic resistant strains. Further studies are being carried out in order to separate the individual components that are present in plant extracts of Calotropis procera and Centella asatica using column chromatography to develop biopesticides which are alternative to synthetic agents. However, it is necessary to determine the toxicity of the active constituents, their side effects and pharmaco-kinetic properties.

\section{Acknowledgements}

I am thankful for constant encouragement and support from Department of Biochemistry, Dr L B Post Graduate College, Visakhapatnam, India.

\section{References}

1. Abubakar S, Ahmed QU, Othman and AS Omar MN (2011) Bacteriostatic and bactericidal activity of the polar and non-polar extracts of Andrographis paniculata against skin disease causing pathogenicbacteria. J. Med. Plant Res. 5, 7-14.

2. Akhtar N and Malik A (1998) Proceragenin, An antibacterial cardenolide from Calotropis procera. Phytochem. 31(8), 2821-2824.

3. Al-Yahya MA, Al-Meshal IA, Mossa JS, AIBadr AA and Tarig M (1990) Saudi plants, A phytochemical and biological approach. Riyadh, King Saud Univ. Press. pp: 31- 34.

4. Ansari SH and Ali M (1999) New oleanene triterpenes from root bark of Calotropis procera. Medic. \& Aromatic Plant Sci. 21(4), 978-981.

5. Ansari SH and Ali M (2001) Norditerpenic ester and pentacyclic triterpenoids from root bark of Calotropis procera (Ait) R. Br. Pharmazie. 56(2), 175-177.

6. Appa Rao MVR, Srinivas K and Koteshwar Rao T (1973) The effect of Mandookaparni (Centella asiatica) on the general mental ability (Medhya) of mentally retarded children. J. Res. Indian Med. 8, 916.

7. Atef $\mathrm{GH}$, Elgamal MHA, Morsy NAM, Duddeck $\mathrm{H}$, Kovacs J and Toth G (1999) Two cardenolides from Calotropis procera. J. Magn. Reson. Chem. 17, 754757.

8. Basak K Samar, Bhaumik Arup, Mohanta Ayan and Singhal Prashant (2009) Ocular toxicity by latex of Calotropis procera (Sodom apple). Indian J. Ophthalmol. 57(3), 232-234.

9. Brooks GF, Butel JS and Morse SA (2004) Jawetz, Melnick and Adelberg's medical microbiology. $24^{\text {th }} \mathrm{ed}$. Lange Med. Brooks/McGraw-Hill. pp: 203 - 642.
10.Elizabeth M, Adrien Szekely Johnson, David W and Warnock (1999) Comparison of E-Test and Broth Microdilution Methods for Antifungal Drug Susceptibility Testing of Molds. J. Clin. Microbiol. 37(5), 1480-1483.

11. Ghosh A, Das BK, Roy A, Mandal B and Chandra G (2008) Antibacterial activity of some medicinal plants. J. Nat. Med. 62, 259-262.

12.Jarrar N, Abu-Hijleh A and Adwan K (2010) Antibacterial activity of Rosmarinus officinalis $\mathrm{L}$. alone and in combination with cefuroxime against methicillinresistant Staphylococcus aureus. Asian Pac. J. Trop. Med. 3(2), 121-123.

13. Jeeshna MV, Manorama S and Paulsamy S(2009) Antimicrobial propertyof the medicinal shrub, Glycosmis pentaphylla. J. Basic Appl. Biol. 3(1\&2), 2527.

14.Johnson M, Wesely EG, Zahir Hussain MI and Selvan $\mathrm{N}$ (2010) In vivo andin vitro phytochemical and antibacterial efficacy of Baliospermum montanum (Willd.) Muell. Arg. Asian Pac. J. Trop. Med. 3(11), 894-897.

15. Kannan RRR, Arumugam $R$ and Anantharaman $P$ (2007) Antibacterial potential of three seagrasses against human pathogens. Asian Pac] Kingston C. Medicinal plants used in the endemic art of Travancore. J. Basic Appl. Biol. 1(1), 38-39.

16. Kareem SO, Akpan I and Ojo OP (2008) Antimicrobial Activities of Calotropis procera on Selected Pathogenic Microorganisms. Afr.J. Biomedic. Res. 11, 105 - 110.

17. Khan AV and Khan AA (2008) Ethnobotany of Eclipta prostrate. Indian J. Tradit. Knowl. 2, 316-320.

18. Koochak H, Nejad SMS and Motamedi H (2010) Preliminary study on the antibacterial activity of some medicinal plants of Khuzestan (Iran). Asian Pac. J. Trop. Med. 3(3), 180-184.

19. Madhuri Sharma and Pandey Govind (2009) Ethnomedicinal plants for prevention and treatment of tumours. Int J Green Pharm. 3, 2-5.

20.Mandal S, DebMandal M, Pal NK and Saha K (2010) Antibacterial activity of honey against clinical isolates of Escherichia coli, Pseudomonas aeruginosa and Salmonella enterica serovar Typhi. Asian. Pac. J. Trop. Med. 3(12), 961-964.

21.Mst Nazma Yesmin, Sarder Nasir Uddin, Sanzida Mubassara and Muhammad Ali Akond (2008) Antioxidant and Antibacterial Activities of Calotropis procera Linn. American-Eurasian J. Agr. \& Environ. Sci. 4(5), 550-553.

22. Murray PR, Baron EJ, Pfaller MA, Tenover FC and Yolken HR (1995) Manual of clinical microbiology. ASM Press. D.C, 6th Ed. pp: 15-18.

23.Nair (2005) Antibacterial activity of some selected Indian medicinal flora. Turkish J. Biol. 29, 41-47.
Research article

CIndian Society for Education and Environment (iSee)
"Medicinal plant"

http://www.indjst.org
V.Vadlapudi Indian J.Sci.Technol. 
24. Olurinola PF (1996) A laboratory manual of pharmaceutical microbiology. Idu, Abuja, Nigeria. pp: 69-105.

25.Raghubir R, Rasik M and Gupta AJ (1999) Healing potential of Calotropis procera on dermal wounds in guinea pigs. J. Ethnopharmacol. 68, 261-266.

26. Rohini kiran Kunta and Varahalarao Vadlapudi (2009) In vitro antibacterial potentiality of Centella asiatica. Biomed. \& Pharmacol. J. 2(2), 293-296.

27. Rout SD, Panda T and Mishra N (2009) Ethnomedicinal Plants used to cure different diseases by Tribals of Mayurbhanj district of north Orissa. EthnoMed. 3(1), 27-32.

28.Schwarz S and Noble WC (1999) Aspects of bacterial resistance to antimicrobials used in veterinary dermatological practice. pp: 163-176.

29.Thangavel Arumugam, Muniappan Ayyanar, Yesudason Justin Koil Pillai and Thangavel Sekar (2011) Phytochemical screening and antibacterial activity of leaf and callus extracts of Centella asiatica. Bangladesh J. Pharmacol. 6, 55-60.

30. Veeramuthu D, Muniappan A and Savarimuthu I (2006) Antimicrobial activity of some ethnomedicinal plants used by Paliyar tribe from Tamil Nadu, India. BMC Complement Altern. Med. 6, pp: 35.

31. Willey JM, Sherwood LM, Woolverton CJ, Presscott, Harley and Klein's (2008) Microbiology. 7th ed. McGraw-Hill Co. Inc. pp: 859-882. 